\title{
A poeira do progresso pede passagem: imagens de natureza e desenvolvimento na floresta amazônica
}

Dust of progress calls for passage: nature and development images in the Amazon Rainforest

\section{RÔMULO DE PAULA ANDRADE'}

Fundação Oswaldo Cruz / Rio de Janeiro, RJ, Brasil

\begin{abstract}
1. Pesquisador e docente do Programa de Pós-Graduação em História das Ciências e da Saúde pela Casa de Oswaldo Cruz (FioCruz). Mestre e Doutor em História das Ciências e da Saúde pela mesma instituição. E-mail: romulopa@hotmail.com
\end{abstract}

RESUMO: Entre 1958 e 1960 foi construído o principal projeto do governo de Juscelino Kubitschek para a região amazônica - a Transbrasiliana, ou rodovia Belém-Brasília. Contando com a abertura de mais de 2 mil quilômetros de estrada em meio à floresta, a estrada foi alvo de diversas críticas por parte de parlamentares e da imprensa de oposição. Diante dessa questão, os meios de comunicação favoráveis ao governo Kubitschek foram acionados para a produção de matérias favoráveis ao empreendimento. Este artigo tem como principal objetivo analisar as imagens produzidas por essas reportagens. Por meio delas é possível trazer à luz as relações entre os projetos de desenvolvimento daquele período e a natureza, a maior impactada por eles. Além disso, o artigo tem objetivo de analisar qual era o lugar da região amazônica nas prioridades do governo Kubitschek.

PALAVRAS-CHAVE: Desenvolvimento. História da imprensa. Amazônia. 
ABSTRACT: Between 1958 and 1960, the main project of the government of Juscelino Kubitschek for the Amazon region was built: the Transbrasiliana, or Belém-Brasilia Highway. With the opening of more than two thousand kilometers of road in the middle of the Amazon rainforest, the project was criticized by opposition media. Faced with this question, the press in favor of the Kubitschek government was activated to produce materials favorable to the enterprise. This article aims to analyze the images produced by these reports. Through them, it is also possible to analyze the relationships between the development projects of this period and the nature, as well as how the Amazon region was seen by the Kubitschek government.

KEYWORDS: Development. Press History. Amazon History.

\section{INTRODUÇÃO}

Objetivo deste artigo é analisar as imagens produzidas por reportagens que cobriram a construção do maior empreendimento voltado para a região amazônica durante os anos de 1946 a 1964: a construção da Transbrasiliana, ou rodovia BelémBrasília. Por meio delas é possível compreender o lugar da natureza e da própria região amazônica nos grandes projetos de desenvolvimento do Brasil do pós-Segunda Guerra Mundial. Entre as memórias do governo de Juscelino Kubistchek, a construção da nova capital, Brasília, é a mais lembrada. Porém, junto com a nova capital foi criado também o "cruzeiro rodoviário", com o objetivo de "integrar o país", como afirmava a propaganda governamental da época. Entre as estradas construídas, o projeto mais ousado foi a Belém-Brasília, que previa a abertura de mais de 2 mil quilômetros por dentro da floresta amazônica, passando por três estados Maranhão, Pará e Goiás) e chegando, por fim, à nova capital. Além de ambiciosa, a construção da estrada foi também um projeto polêmico, com diversas denúncias por parte de jornais opositores, bem como reportagens laudatórias produzidas pelos meios de comunicação que apoiavam Juscelino. Somado a isso, a região amazônica passava por uma série de diferentes projetos e perspectivas de mudança, com a Superintendência de Valorização Econômica da Amazônia (SPVEA), primeira agência de desenvolvimento regional do país. As fotografias produzidas e divulgadas pela imprensa do período 
representam uma oportunidade de compreender a articulação entre as perspectivas de natureza por parte do governo, bem como o posicionamento dos meios de comunicação perante os grandes projetos de desenvolvimento.

O contexto de produção das imagens é o primeiro assunto a ser tratado no artigo. Por meio delas é possível identificar os aspectos do que seria a "modernidade" propagandeada pelo governo de Juscelino Kubitschek, além da construção de estradas e da relação entre o então presidente e a imprensa da época. $\bigcirc$ último projeto voltado para a região amazônica de tamanho vulto e a causar tanto impacto em escritos locais e nacionais tinha sido a construção da ferrovia Madeira-Mamoré no início do século XX que, nas palavras de Francisco Foot Hardman, foi o "espetáculo privilegiado da civilização capitalista na selva". ${ }^{2}$ A indústria das estradas de ferro e sua internacionalização representaram, durante a segunda metade do século XIX, um dos fatores básicos para a articulação do mercado mundial. ${ }^{3}$ Como aponta Borges, a implantação das estradas de ferro no Brasil significou muito mais que uma simples inovação nos meios de transporte e comunicação; foi na verdade o marco de uma mudança na organização econômica: do sistema mercantil-escravista para o modo capitalista de produção. ${ }^{4}$ Com um contexto completamente diferente, as estradas passaram a representar o "moderno" em contraposição ao "atraso" das ferrovias, muitas desmanteladas e substituídas a partir dos anos 1950. Qual seria o impacto da construção da Belém-Braślia para uma região amazônica vista nas décadas de 1950 e 1960 como "subdesenvolvida" e, na palavra de parlamentares daqueles anos, "atrasada"? Se em fins de século XIX e início do XX a ferrovia era o signo de modernidade e uma possível entrada da Amazônia em determinada "civilização", nos anos JK a abertura de uma estrada no meio da floresta amazônica seria a oportunidade ideal de retirar a região de estigmas históricos e recorrentes, como o seu "isolamento", superado pela "integração" promovida pelo cruzeiro rodoviário. Bertha Becker caracteriza esse período como "fase do planejamento regional" da história da Amazônia, que se situa entre 1930 e 1985, sendo reflexo do nacionaldesenvolvimentismo vigente, marcado pelo planejamento governamental Imesmo que com poucas ações efetivas), pela modernização de instituições estatais e pela crescente intervenção pública na economia e no território. ${ }^{5}$

A natureza e a floresta amazônica seriam impedimentos a esse processo; autênticas vilãs que deveriam ser superadas para dar lugar ao progresso e à modernidade, representados pelas máquinas Caterpillar e pelos carros, símbolos do rodoviarismo juscelinista. Analisando as diversas escolas críticas do realismo fotográfico (a ideia de que há uma simples transposição da realidade para a imagem), Mauad destaca que um dos passos para uma perspectiva nessa chave é compreender que entre o objeto e sua representação fotográfica existe uma série de ações convencionadas,
2. Hardman (2005, p. 35).

3. Hardman (2005, p. 150).

4. Borges (2011, p. 31).

5. Cf. Becker (2004). 
6. Mauad (2008, p. 33).

7. Cf. Lacerda (2012). cultural e historicamente. Dessa forma, a fotografia em si é uma escolha entre tantas outras possíveis, uma atitude estreita com a visão de mundo do indivíduo responsável pelo "clic". 6 Dessa forma, as máquinas aqui apresentadas são signos de uma ideia de modernidade calcada nos padrões urbano-industriais, relacionando-se ao intenso e dinâmico mercado editorial do período, com o advento de revistas como $\bigcirc$ Cruzeiro e Manchete. Um reflexo disso é o advento das fotorreportagens, cujas imagens tinham a intenção de destacar os "50 anos em 5" de forma tangível em todos os lugares, até mesmo em terras distantes das sedes dessas revistas e de seus públicos leitores.

Em trabalho sobre o lugar da fotografia nos arquivos, Aline Lacerda destaca que os registros fotográficos são vistos de forma autorreferente, sem ligação evidente com o restante do arquivo ou de sua entidade produtora. ${ }^{7}$ Dessa forma, como perspectiva metodológica o artigo pretende inserir as imagens, na medida do possível, em seus contextos originais de (re)produção, contando com as legendas que já estavam no suporte. Tais indícios colaboram para uma tentativa de constituir, mesmo que de forma parcial e seletiva, possíveis intenções dos criadores dessas imagens, cujos critérios passavam por escolhas editoriais e pelos objetivos das próprias reportagens. As imagens aqui destacadas foram produzidas a partir das zonas de contato dessas dimensões. Um tema que percorrerá o texto é a oposição, nas fotografias e nas legendas que as acompanham, entre os humanos e a natureza. Vista como vilã de um processo teleológico cujo rumo inexorável seria uma "civilização" aos moldes urbano-industriais, a natureza foi associada a um passado que deveria ser esquecido, suplantado pela estrada, o "novo". Para a compreensão desses registros, dois pontos serão centrais no artigo: a contextualização das revistas em que as fotos estão inseridas e as percepções sobre a natureza que esses escritos trazem. Inicialmente as (boas) relações estabelecidas entre Juscelino Kubitschek e a imprensa serão privilegiadas. Outro ponto relevante deste texto é demonstrar a importância que a propaganda política tinha (e tem) também em tempos democráticos, ainda que a historiografia, de forma geral, se concentre mais em períodos ditatórias. As redes estabelecidas por JK com entes públicos e privados são uma pequena amostra da complexidade desse período.

\section{MODERNIDADE E IMPRENSA NOS ANOS JK}

Quando se analisam os primeiros artigos sobre a figura de Juscelino Kubitschek na imprensa (à época de sua candidatura e vitória), comparados aos do período da construção da nova capital e da estrada, é perceptível a mudança de postura de alguns veículos, bem como a radicalização de outros. Neste artigo nos dedicamos 
especialmente aos favoráveis à construção da BR-14, mas breves notas sobre a imprensa durante o governo JK são necessárias para o andamento do trabalho. A Tribuna da Imprensa, dirigida pelo udenista Carlos Lacerda, manteve-se coerente durante todo o governo Juscelino Kubitschek, ao qual sempre se apresentou contrária, desde o início até os grandes projetos do período. A candidatura de JK, então governador de Minas Gerais, foi contestada pela Tribuna, além do Diário Carioca e do Correio da Manhã. Estes dois últimos posteriormente seriam favoráveis ao governante, enquanto o Tribuna continuaria firme em suas críticas ao "presidente varguista", nas palavras de Carlos Lacerda. ${ }^{8}$ Eram tempos democráticos e de convívio (sempre tenso) com o contraditório, porém Juscelino possuía bom suporte de grande parte dos meios de comunicação naqueles anos, destacando-se os jornais e as rádios pertencentes a Assis Chateaubriand, o grupo Globo de Roberto Marinho e, enfim, a revista Manchete, do grupo Bloch. ${ }^{9}$ É possível apontar um desgaste nessa relação no término do governo, com as crescentes denúncias de corrupção dos grandes projetos desenvolvimentistas. Porém, na maior parte dos anos a boa relação do governante com a imprensa possibilitou maior divulgação dos atos da presidência no período, transformando as reportagens, em alguns momentos, quase em uma extensão da propaganda oficial. Um exemplo é a publicação, por parte da editora SPVEA (pertencente ao governo), de artigos de $\bigcirc$ Globo sobre a Belém-Brasília. Outras reportagens também foram compiladas em livros da mesma editora, dando origem ao curto periódico Cadernos Belém-Brasilia, com a publicação de textos do jornal Última Hora e da Manchete. A palavra de ordem nos jornais apoiadores do governo era o confronto entre os dois "Brasis", onde o "moderno" superaria o "arcaico", e a ferramenta para isso seria o desenvolvimentismo e os grandes projetos de Juscelino. ${ }^{10}$

A rodovia Belém-Brasília foi um exemplo da divulgação do desenvolvimentismo juscelinista pelos apoiadores do governo. Reverberações de antigos clichês sobre a região amazônica encontram eco nessas reportagens. Termos como "vazio demográfico" e "natureza perigosa" são bastante recorrentes nos textos. Diante da dificuldade de construir uma estrada em meio à floresta, foram dados contornos épicos à empreitada. Um exemplo é o livro do jornalista Lauro de Azevedo Rolim, Transbrasiliana-um poema brasilista, onde a BR-14 e os profissionais que a idealizaram e construíram se transformam em personagens de uma epopeia, inseridos em um combate entre humano e natureza, do qual o primeiro sairia ganhando, graças às "máquinas do progresso":

Entre a máquina e a selva, o duelo tremendo a que empresta o machado um papel decisivo, abatendo, implacável, os gigantes da mata! Ao furor combativo toda a selva estremece. 
11. Rolim (1960, p. 14).

12. Cf. Martins (2007).

13. Pádua (2012, p. 24)

14. Cf. Pádua (2002).

15. Cf. Kossoy (2002).

16. Barthes (2002, p. 132).
A fauna, amedrontada, se embrenha

Mas na face da terra encantada e ubertosa

vai ficando o perfil retilíneo da estrada! ${ }^{1 !}$

A natureza, nas palavras desses escritos, era vista como a grande vilã do progresso. É importante, inicialmente, tomar como referência a observação de Martins segundo a qual, em relação à natureza, não existem somente interesses. ${ }^{12}$ Em qualquer sociedade, a natureza é fonte de valores e representações intrincados, complexos, contraditórios, que nutrem artes, religiões, mitos e saberes. A natureza seria, assim, uma construção cultural, concretizada nas concepções de mundo, sempre com a ideia de oposição ao outro, conforme José Augusto Pádua assinala:

De um lado, a ideia de natureza serve como uma espécie de eixo conceitual que dá sentido ao nosso entendimento do universo. Ela fundamenta a construção conceitual que dá sentido ao nosso entendimento do universo. Ela fundamenta a construção conceitual da experiência de que existe coerência ontológica no mundo em que vivemos. Por sua vez, a imagem de ser humano e de história humana se construiu em grande parte por oposição à natureza: arte versus natureza; ordem social versus natureza; técnica versus natureza; espírito versus natureza etc. Em outras palavras, um conjunto de oposições que procuram demarcar, por diferenciação ou por identificação, a especificidade do fenômeno humano em relação à natureza. ${ }^{13}$

Estamos nos referindo aqui a um constructo cultural específico, fruto de prefigurações seculares sobre a região amazônica, que de certa forma radicalizou os discursos anteriores sobre o local da natureza nos projetos governamentais. As alternativas a esse discurso de "destruição" no país datam do período colonial, por mais que as preocupações não fossem necessariamente conservacionistas, para utilizar um termo contemporâneo. ${ }^{14}$

A construção da Belém-Brasília gerou fotografias de forte caráter simbólico. A produção da obra fotográfica diz respeito ao conjunto de mecanismos internos do processo de construção da representação, concebido conforme certa intenção, construído e materializado estética, ideológica e tecnicamente. ${ }^{15}$ Essas fotografias se relacionam a uma tradição nacional e internacional de promover uma fixação de memória e, neste caso, se prestam a uma finalidade propagandística, financiada por instituições oficiais interessadas em divulgar certo tipo de progresso. Assim, essas fotos, como afirma Barthes, não seriam meras "cópias" do real, mas sim emanações, trechos, vestígios de um passado já vivido. Não seriam meras reproduções. ${ }^{16}$ Tais imagens trazem as concepções de mundo dos seus autores e do contexto em que foram produzidas. Na Figura 1 observamos o presidente e o ministro Lúcio Meira em um momento de descanso das obras. Fotografar o presidente no campo onde estariam 
ocorrendo as obras, assim como dar destaque ao aperto de mão entre o presidente e os moradores locais (Figura 5), é colocar em cena o principal ator político do projeto, comprometido com as possíveis mudanças que a obra traria.

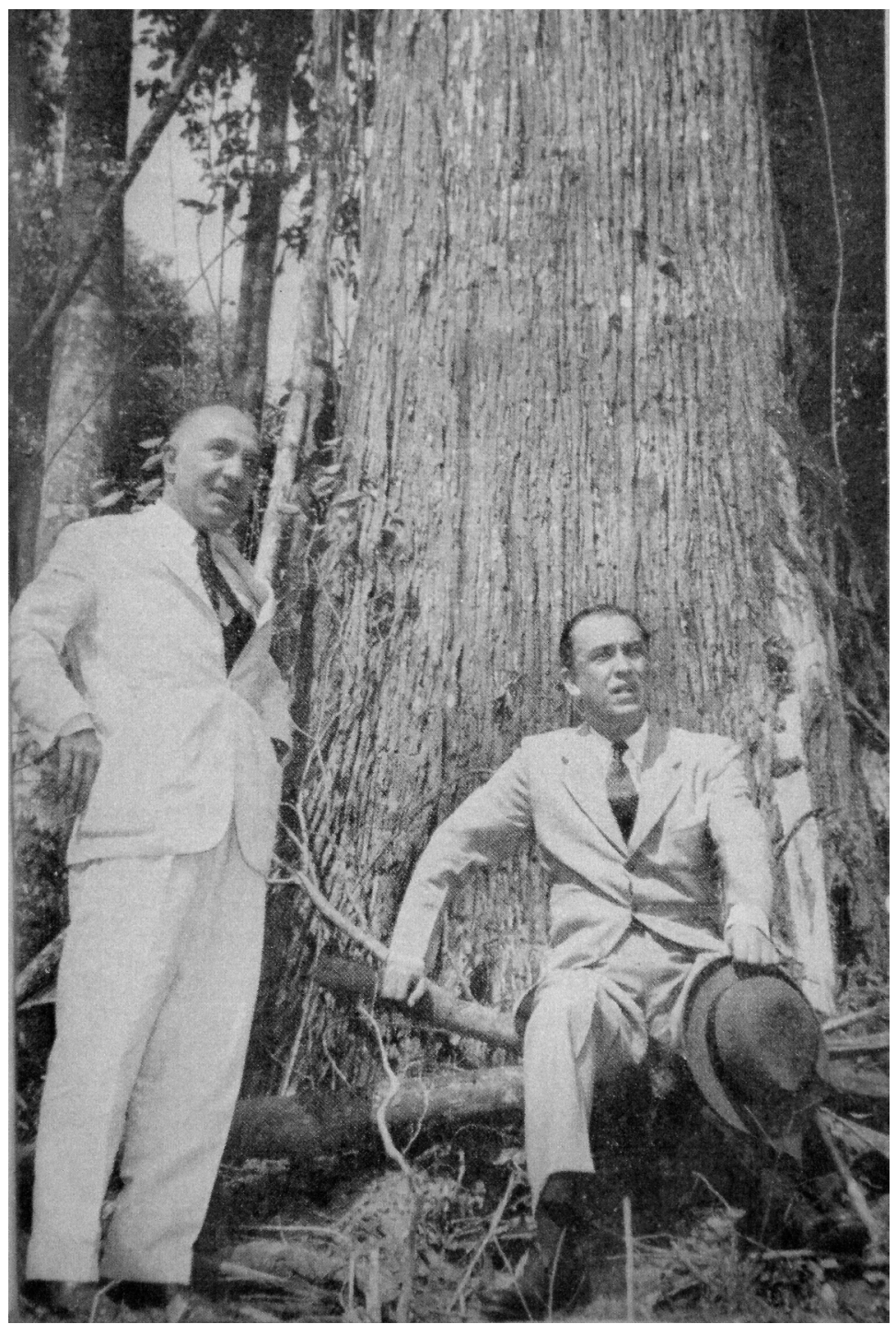

Figura 1 - Juscelino Kubitschek e Lúcio Meira. Fotógrafo não identificado, 1960. Fonte: BRASIL. O planejamento transforma a Amazônia. Rio de Janeiro: SPVEA, 1960.

Para compreender a mensagem implícita nas fotografias é necessário cotejálas com os discursos do período, buscando verificar com que substrato do real estamos nos defrontando. Uma possível interpretação se encontra na análise da fala de JK sobre a natureza, na qual ele reafirma as concepções presentes nas peças publicitárias da época da construção e inauguração da BR-14. Realmente alguns episódios dos dois anos do projeto ajudaram a dar os contornos épicos pretendidos pelo governo JK. No trecho final da estrada alguns acontecimentos 
17. O episódio da morte de Bernardo Sayão deu origem a uma série de comoções. $\mathrm{O}$ engenheiro inaugurou $\mathrm{o}$ cemitério de Brasília e teve a memória bastante laureada, com a publicação de biografias e textos comemorativos. Para mais informações, cf. Silva (2009).

18. Kubitschek (2000, p. 232). teriam papel fundamental na memória construída sobre a rodovia: a morte de Rui de Almeida, engenheiro responsável pelo desmatamento da frente de Brasília, e principalmente a morte de Bernardo Sayão. $O$ engenheiro, às vésperas do encontro em Ligação (nome criado para homenagear a conexão das duas vias), encontravase em uma espreguiçadeira após o almoço, quando o galho de uma árvore, isolada após o desmatamento, se partiu e o atingiu. Sua morte representou a criação do mito em torno do engenheiro, tido como bandeirante moderno pela propaganda presidencial. ${ }^{17}$ Alguns meses após a morte de Sayão, ocorreu o evento que ligaria os trechos da rodovia, em especial dois: o que viera de Belém e o que tinha origem em Brasília. $\bigcirc$ ato simbólico que daria concretude a essa definitiva conexão seria a derrubada de um jatobá pelo próprio presidente (Figura 2). A forma como o acontecimento é narrado por Juscelino expõe o papel daquela árvore em particular (e da mata em geral) no seu projeto de governo:

impedindo a ligação [...] [lá estava] a árvore imensa. Media-a com os olhos. O caule projetava-se contra o céu quase sem galhos e abria-se, lá em cima, a fronde majestosa. [...] o que parecia impossível estava acontecendo. [...] Num canto, via-se um trator amarelo. Era a arma de que me utilizaria para a batalha contra o último guerreiro. [...] sentia-me orgulhoso da tarefa que me fora reservada. Dera a ordem para derrubar a primeira árvore e eu próprio iria fazer a última. [...] ouviu-se um estrondo subterrâneo das raízes que se desprendiam. [...] $\bigcirc$ último tamoio caíra, e, com sua morte, desfizera-se a superstição da inviolabilidade da selva. ${ }^{18}$

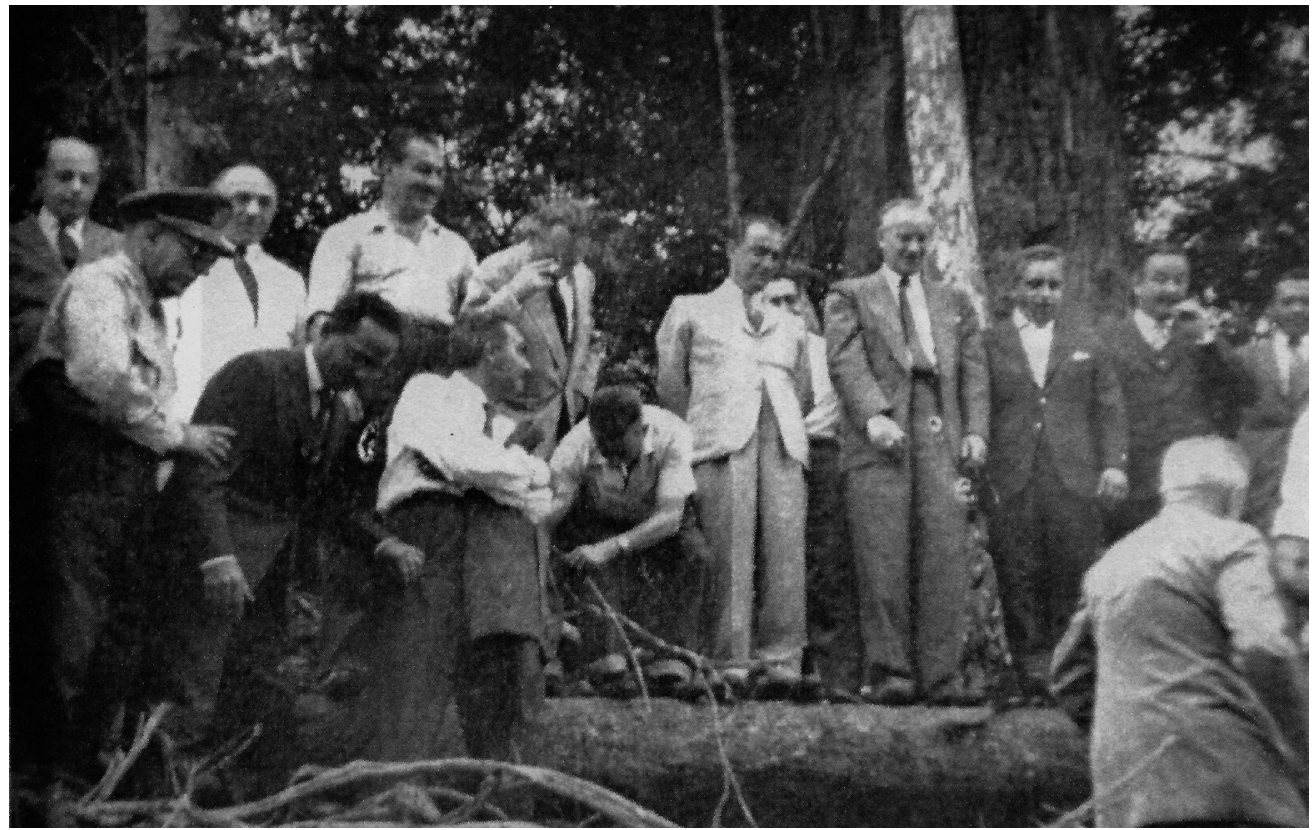

Figura 2 - Juscelino Kubitschek e diplomatas de diversos países na construção da Belém-Brasília. Fotógrafo não identificado, 1960. Fonte: BRASIL. O planejamento transforma a Amazônia. Rio de Janeiro: SPVEA, 1960. 
Ora, a natureza não é uma ideia, mas muitas ideias, significados, pensamentos e sentimentos, empilhados uns sobre os outros, frequentemente da forma menos sistemática possível. ${ }^{19}$ Seria, assim, uma criação da mente humana, e esta, por mais que se esforce para ver o que a natureza é objetivamente, acaba prendendo o olhar nas grades da própria consciência e na rede de significados humanos. Por isso é imprescindível descobrir como uma cultura de determinada época avaliou e representou a natureza e sua paisagem característica. Se por um lado a floresta significa perigo, por outro traz ideias de deslumbramento diante de seu tamanho. Em reportagem sobre a rodovia, que posteriormente seria publicada nos Cadernos Belém-Brasília, Arnaud Pierre, jornalista do Correio da Manhã, afirmou que o que mais o impressionava era a floresta: "a hileia domina de tal modo a todos aqui, principalmente a nós, que tudo observamos para escrever, que se eu não me precatar, ela me descaminha nesta reportagem [...] Quero me desvencilhar da floresta de vez" 20 .

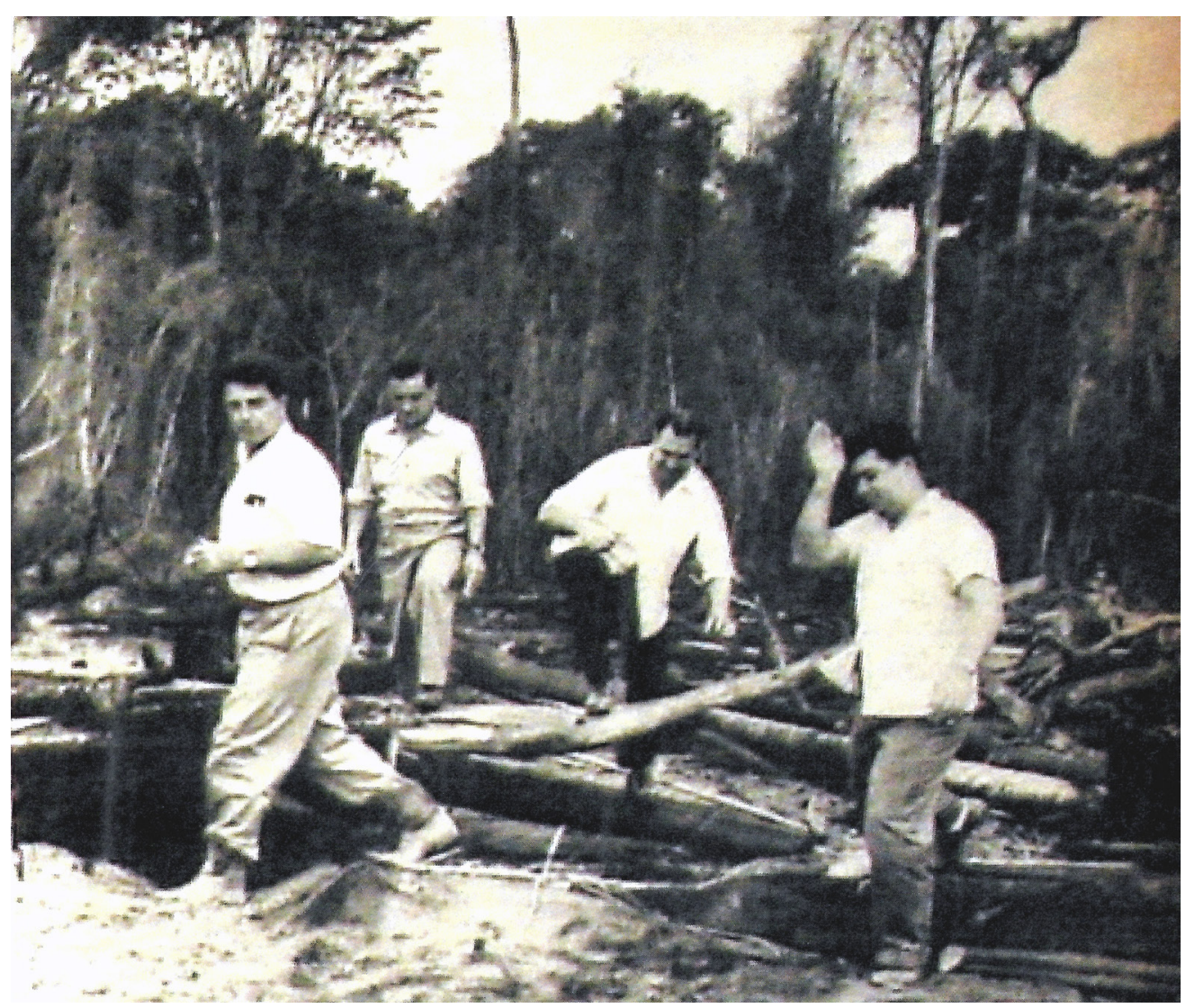

Figura 3 - Bernardo Sayão, Waldir Bouhid e outros na construção da estrada. Fotógrafo não identificado, 1960. Fonte: PIERRE, Arnaud. Primeira viagem na Belém-Brasília. Rio de Janeiro: SPVEA, 1960. (Cadernos Belém-Brasília, v. 4). 
21. Cf. Corrêa (2013).

22. Cf. Corrêa (2013).

23. Vaitsman (1958, p. 25).

24. Vaitsman $(1958$, p. $25-$ 26).
Assim como as percepções de natureza, é necessário apontar qual ideia de paisagem esses jornalistas trouxeram para suas reportagens. Em artigo de 2013 , Dora Corrêa fez um balanço historiográfico sobre esse conceito, o que ajuda a descortinar as concepções presentes nessas imagens sobre a Amazônia, vista por tais reportagens como um lugar pronto (e urgente) para a intervenção estatal. ${ }^{21}$ A partir de um amplo panorama historiográfico, Corrêa destaca três concepções que de certa forma estão presentes na produção das imagens usadas em seu artigo. A primeira analisa a descrição de paisagens de forma ambígua, encarando-a tanto como uma percepção objetiva do real (podendo ser lida sem interferência externa, de forma objetiva) quanto subjetiva, já que a descrição de uma paisagem pode englobar mais que o sentido pelos olhos. A segunda, mais tributária da História Ambiental, entende a paisagem como um conjunto de elementos concretos, sendo ao mesmo tempo a percepção e o percebido. Assim, é uma leitura objetiva do espaço filtrada pela subjetividade. Por fim, inspirada nos estudos de Juan Manuel Gonzalez, há a percepção de que a paisagem é a expressão material de uma ideologia, ou seja, um conjunto de elementos concretos, e que essa ideologia interfere na relação dos humanos com o meio ambiente. ${ }^{22}$ Dessa forma, é possível destacar que os jornalistas e fotógrafos que produziram essas imagens e reportagens trouxeram consigo concepções históricas sobre a região amazônica que interferiram de forma decisiva na escolha do que clicar ou do que relatar. Maurício Vaitsman, repórter d'O Globo, ressalta em sua reportagem (também transformada em livro) intitulada Brasilia e Amazônia que a floresta amazônica durante séculos desafiara o "homem civilizado" com sua "exuberância prodigiosa" e seus "mistérios insondáveis". Com as máquinas, "espadas do progresso", os homens estariam descobrindo um "mundo novo", "desconhecido" e protegido pela "agressividade da natureza" ${ }^{23}$ A própria chamada da reportagem afirmava que os trabalhadores estariam diante de um sonho: a violação da selva, uma "barreira para o progresso", com os pneus dos tratores:

A selva amazônica, que desafiava o progresso desde os tempos do Grão-Pará, está sendo
finalmente dominada pela máquina e pelo homem. Centenas de quilômetros de modernas
rodovias cortam a floresta bruta, transmitindo o fluxo da civilização ao "hinterland" cabo-
clo, escravizado pelo extrativismo da borracha. Um punhado de homens está mudando a
fisionomia da Amazônia para integrá-la na unidade nacional do país. ${ }^{24}$

De que forma tal discurso se insere nas imagens? Para responder essa pergunta, é necessário conhecer, compreender e interpretar - à luz das evidências históricas, que têm na imagem fotográfica uma das manifestações - os sentidos que os indivíduos, isoladamente ou em grupo, quiseram atribuir 
às suas práticas sociais. ${ }^{25}$ Compreendemos aqui tais imagens relacionadas aos discursos produzidos no período - e não isoladas deles. Dessa forma, as fotografias buscam registrar a floresta dominada pela ação humana. Uma característica comum às três fotos selecionadas é a posição dos personagens perante as árvores (Figuras 1, 2 e 3). De um lado é possível perceber, nas duas primeiras imagens, a representação política do sucesso da obra, com membros do alto escalão governamental, demonstrando o êxito da construção da estrada. Na Figura 3, personagens fundamentais para a obra, como Bernardo Sayão e Lino Teixeira, trazem à luz a questão nacionalista do período, como visto na legenda que os chama de "verdadeiros generais da conquista da Amazônia". Um dos discursos mais comuns na época lque de certa forma encontra eco nos dias de hojel é a necessidade de "conquista" da Amazônia para afastá-la da "cobiça internacional". 26

Assim, a vitória sobre as condições naturais e o "efetivo domínio" daquelas plagas reforçavam a vitória do Brasil sobre ele mesmo. Rememorando imagens da Marcha para o Oeste, tratava-se do imperialismo brasileiro conquistando a si próprio. A Marcha, programa de colonização criado por Cassiano Ricardo durante - Estado Novo, foi pródiga em ressaltar o "espírito bandeirante" e a "conquista" das terras brasileiras. ${ }^{27}$ Pouco efetivo, o programa criou ideias-forças que foram apropriadas pelos presidentes tanto do período democrático quanto do período ditatorial pós-1964, em especial na construção da rodovia Transamazônica. Para o historiador Peter Burke, as imagens são testemunhas dos estereótipos (e também das mudanças graduais) pelos quais indivíduos ou grupos veem o mundo social. Dessa forma, as imagens aqui apresentadas representam também a concepção construída por esses agentes políticos e culturais sobre a região amazônica e seu processo de desenvolvimento. ${ }^{28}$

A Figura 2 não pode ser descolada do texto que a acompanhava. Além do caráter simbólico já referido, a fotografia foi também a celebração do encontro entre o presidente e os embaixadores da Inglaterra, da Alemanha, do Equador e da Tchecoslováquia. A viagem serviria para os representantes de nações amigas do Brasil conhecerem aspectos do país. Assim, JK mostraria a outros países o que seria o desenvolvimento nessas regiões. Na afirmativa de Vaitsman, "quatro embaixadores [...] tiveram o privilégio de ver como o homem brasileiro e as máquinas estão afrontando a misteriosa floresta amazônica". ${ }^{29}$ Além de possibilitar à comitiva estrangeira conhecer aspectos da cultura local e sua culinária (foi oferecido um banquete em plena picada), esse ato demonstrou a forma como a imagem do país deveria ser levada ao exterior: um lugar que preservava sua cultura tradicional, mas que também possuía características modernas, como demonstrava a construção de estrada.
25. Borges (2008, p. 112).

26. Um livro símbolo desse ideário é a obra "Amazônia e a Cobiça Internacional”, de Arthur Cézar Ferreira Reis, lançado em 1965.

27. Cf. Ricardo (1970); Velho (1976); Silva (2009).

28. Burke (2004, p. 232).

29. Vaitsman (1958, p. 57). 
30. Cf. Borges (2008).

31. Vaitsman (1958, p. 50).
Retornando ao argumento de Borges, a fotografia pressupõe um jogo de inclusão e exclusão, ou seja, trata-se de escolhas que, como tal, não constituem apenas uma representação do real, mas integram um sistema simbólico pautado por códigos oriundos da cultura que as produz..$^{30} \mathrm{Um}$ aspecto de exclusão notado em todas as fotografias levantadas é a ausência de elementos indígenas. Uma explicação é possivel: em grande parte dos textos aqui selecionados eram apontados chistes de membros da oposição ao governo, sugerindo que os jornalistas e políticos seriam atacados por índios e onças. Quando os indígenas surgem nos textos são somente oriundos de "tribos dóceis" ou "devidamente civilizados", e parte do grupo de mateiros (trabalhadores responsáveis pela abertura das picadas) constituía-se de indígenas "civilizados". ${ }^{31}$ No local onde Bernardo Sayão teve sua vida ceifada foi erguida uma cruz, simbolizando e reforçando o mito do "pioneiro" (Figura 4).

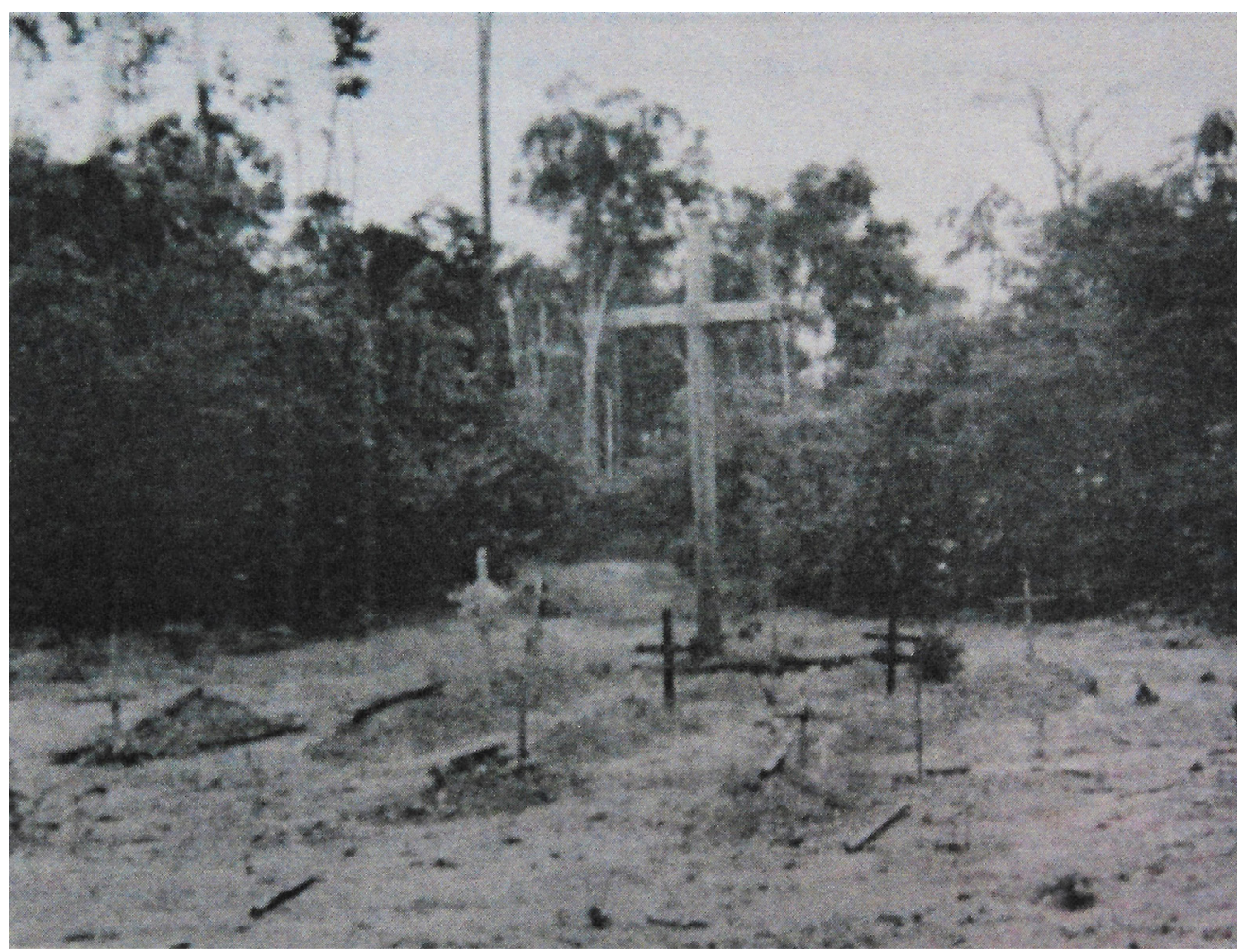

Figura 4 - Túmulo improvisado de Bernardo Sayão. Fotógrafo não identificado, 1960. PIERRE, Arnaud. Primeira viagem na Belém-Brasília. Rio de Janeiro: SPVEA, 1960. (Cadernos Belém-Brasília, v. 4). p. 13

Como temos demonstrado, o discurso sobre progresso/desenvolvimento versus natureza baseou-se na antinomia entre esses polos; melhor dizendo, a existência de um teria como pressuposto a inexistência do outro. Rossi tece considerações sobre tal relação: 
Essa ideia de progresso que não põe limite às esperanças dos homens, que identifica o progresso como um processo necessário, [...] pertence irremediavelmente ao passado, é expressão de um mundo que não é mais o nosso. Nesse mundo, o "sucesso" parece baseado nas ilimitadas capacidades criativas do homem; a ideia de luta e de conquista se associa ao culto pelo homo faber capaz de domesticar a natureza e de civilizar os povos bárbaros; a sensação de aventura no grande jogo da sociedade e na grande competição entre o homem e a natureza acompanha a fé na continuidade e na eternidade do regnum hominis. A natureza se configura, assim, como uma entidade integralmente dominável. ${ }^{32}$

autor ressalta que uma das ideias-forças desse progresso seria identificar, na luta entre humano e natureza, a capacidade de provocar ilimitados melhoramentos e interpretá-la como mais um elemento do progresso. Somada a isso há a percepção sobre as paisagens da Amazônia e as possibilidades, vistas naquele momento histórico como factíveis, de intervenção sobre aquela realidade.

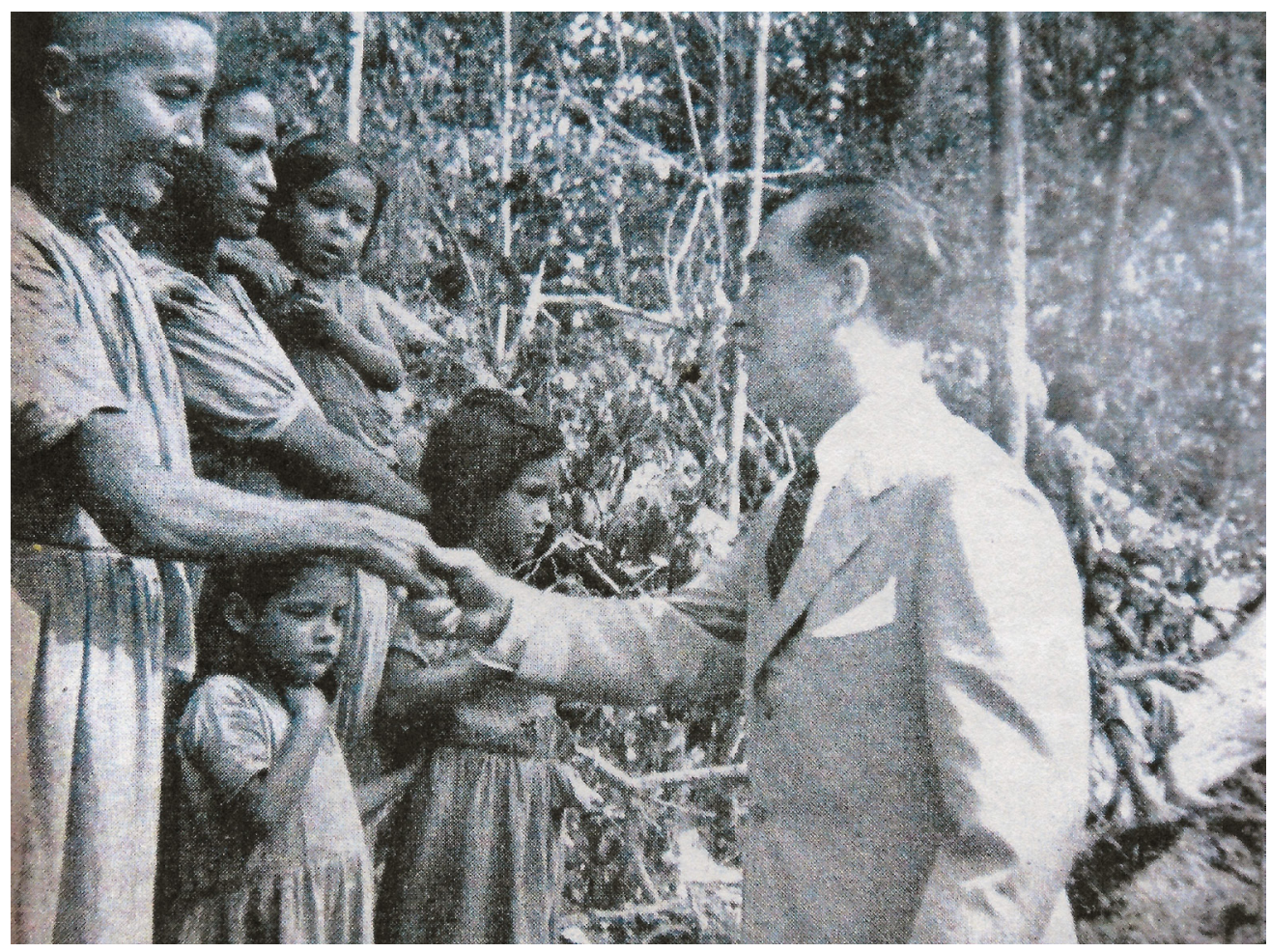

Figura 5 - Juscelino Kubitschek cumprimentando populares na construção da estrada. Fotógrafo não identificado, 1960. PIERRE, Arnaud. Primeira viagem na Belém-Brasília. Rio de Janeiro: SPVEA, 1960. (Cadernos Belém-Brasília, v. 4). p. 10

Constituem-se assim duas visões sobre a natureza: ela seria simultaneamente objeto de domínio e de reverência; deveria ser "torturada" e "dobrada a serviço do homem". Não é difícil identificar que uma percepção de vitória rege os objetivos de expor e divulgar as Figuras 6, 8 e 9: máquinas abrindo picadas na mata e a 
abertura de um campo de pouso em meio à floresta amazônica dão o tom épico dessa "luta" narrada pelos meios de comunicação do período. Afinal, se os discursos oficiais do próprio presidente davam conta da intransponibilidade da natureza, nada mais comemorativo que mostrar a primeira clareira aberta na BelémBrasília. Alguns aspectos da construção da estrada eram realmente impressionantes: várias reportagens descrevem o lançamento de mantimentos e até animais vivos dos helicópteros e aviões para os trabalhadores, como mostra a Figura 7. As imagens desempenharam, pois, importante papel na "construção cultural" da sociedade, sendo testemunhas dos arranjos sociais e sobretudo das maneiras de ver e pensar o passado. ${ }^{33}$

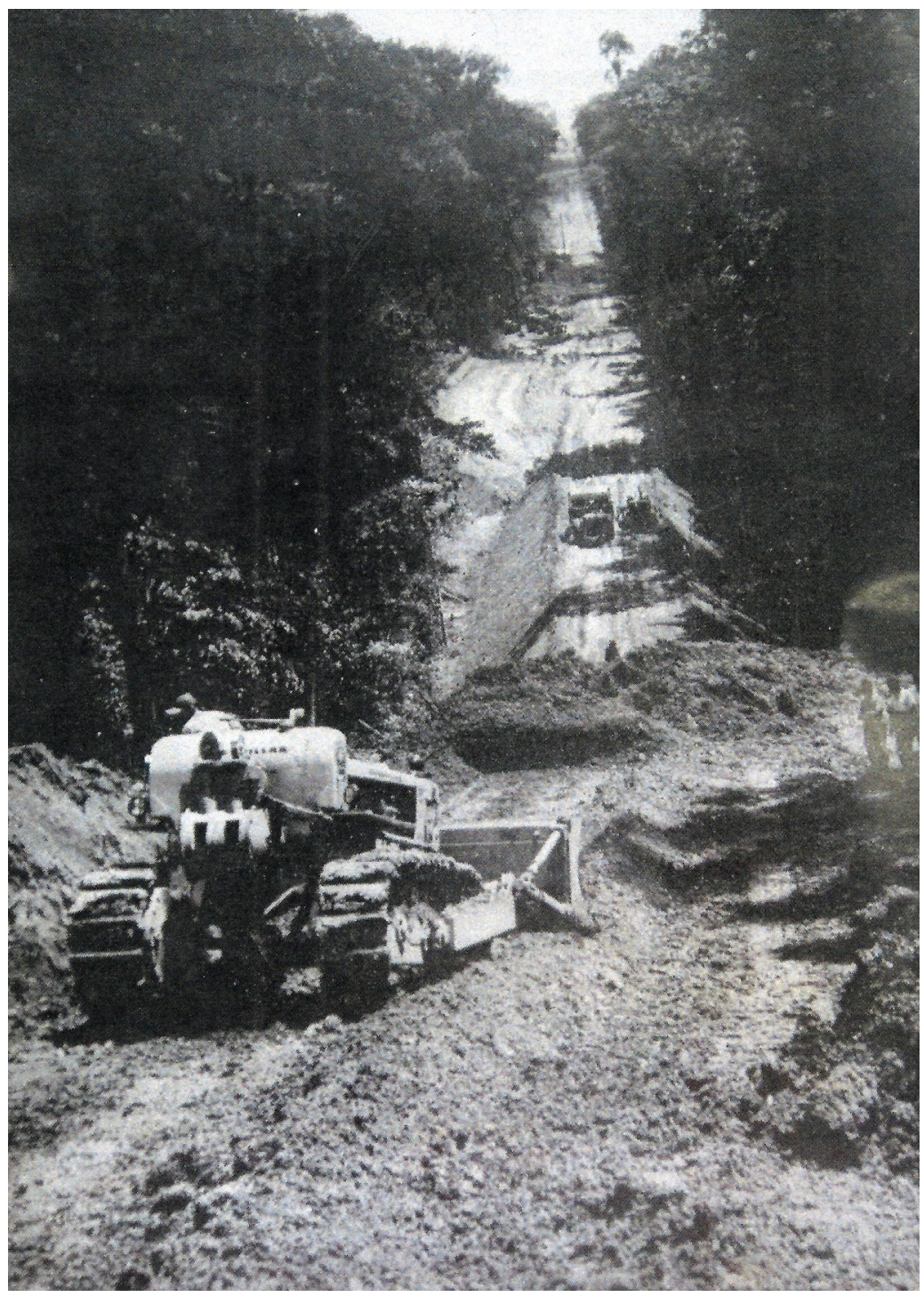

Figura 6 - Primeira picada na mata. Fotógrafo não identificado, 1960. PIERRE, Arnaud. Primeira viagem na Belém-Brasília. Rio de Janeiro: SPVEA, 1960. Kadernos Belém-Brasília, v. 4). p. 6 
A fotografia, apesar de conter amplo potencial de informação, não substitui a realidade tal como se deu no passado. Ela apenas traz informações visuais de um fragmento do real, selecionado e organizado estética e ideologicamente. ${ }^{34}$ Dessa forma, as imagens aqui apresentadas trazem determinada visão sobre a natureza e sua relação com o elemento humano. Em uma primeira leitura, seria possivel afirmar que tal concepção constitui-se hegemônica. Porém, em alguns momentos pode-se perceber, mesmo que de forma breve, vozes dissonantes nesse processo. Maurício Vaitsman, em uma de suas reportagens à época da construção da BR-14, apontou vozes contrárias ao desmatamento, que estavam temerosas de que a penetração pela floresta pudesse causar danos irreparáveis, com a exploração indiscriminada das matas. ${ }^{35}$ Sua posição pessoal, entretanto, era outra. Afirmava também que a colonização do país só poderia ser feita com o sacrifício de boa parte das florestas, e não havia motivos para alarme em excesso com os "pequenos estragos" que a obra teria causado.

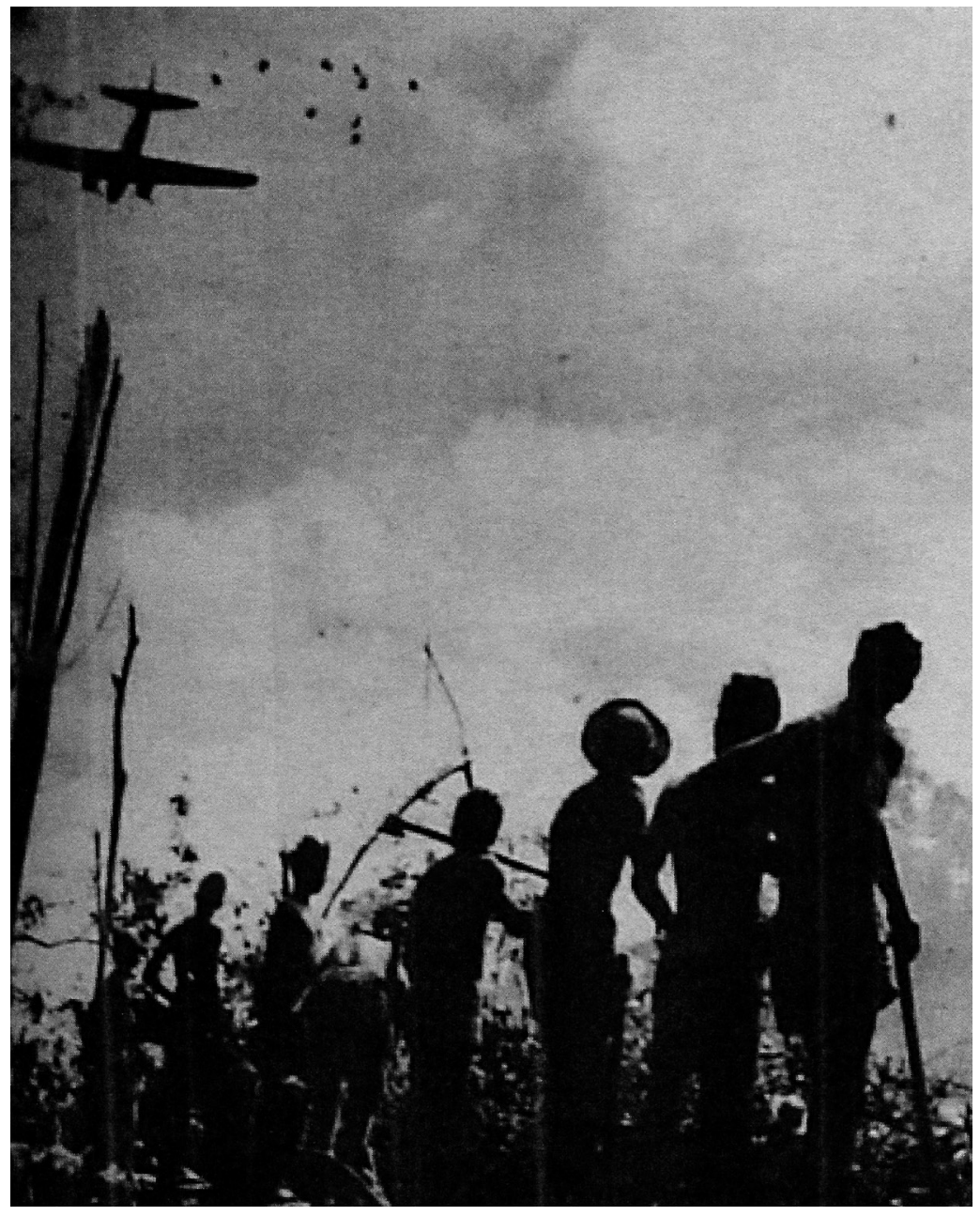

Figura 7 - Abastecimento aéreo dos trabalhadores Belém-Brasília. Fotógrafo não identificado, 1959. Fonte: FlORES, Aluízio. Belém-Brasília: Manchete assiste à conquista da Amazônia. Manchete, Rio de Janeiro, ano 10, n. 7, p. $15-$ 25,1959 . p. 20 
36. Vaitsman (1958, p. 53).

37. Cf. Vaitsman (1958).
Vaitsman desaconselhou também a adoção de medidas de proteção rigorosas à floresta amazônica, pois "o remédio seria pior do que o mal". ${ }^{36}$ Assim, a destruição da floresta seria um sacrifício necessário para o progresso desenvolvimentista. Deixando de lado temporariamente o maniqueísmo que dominava seus escritos - e provavelmente por dever do ofício, já que se tratava do presidente do órgão que publicava suas reportagens - Vaitsman cita também Waldir Bouhid, diretor da SPVEA, que, em palestra aos governadores dos estados pelos quais a rodovia passava, aconselhava que a ocupação das terras próximas à rodovia fosse regulamentada, visando a resguardar as florestas da destruição e permitir uma colonização que pudesse prosperar sem a necessidade de prisão dos mateiros. ${ }^{37}$

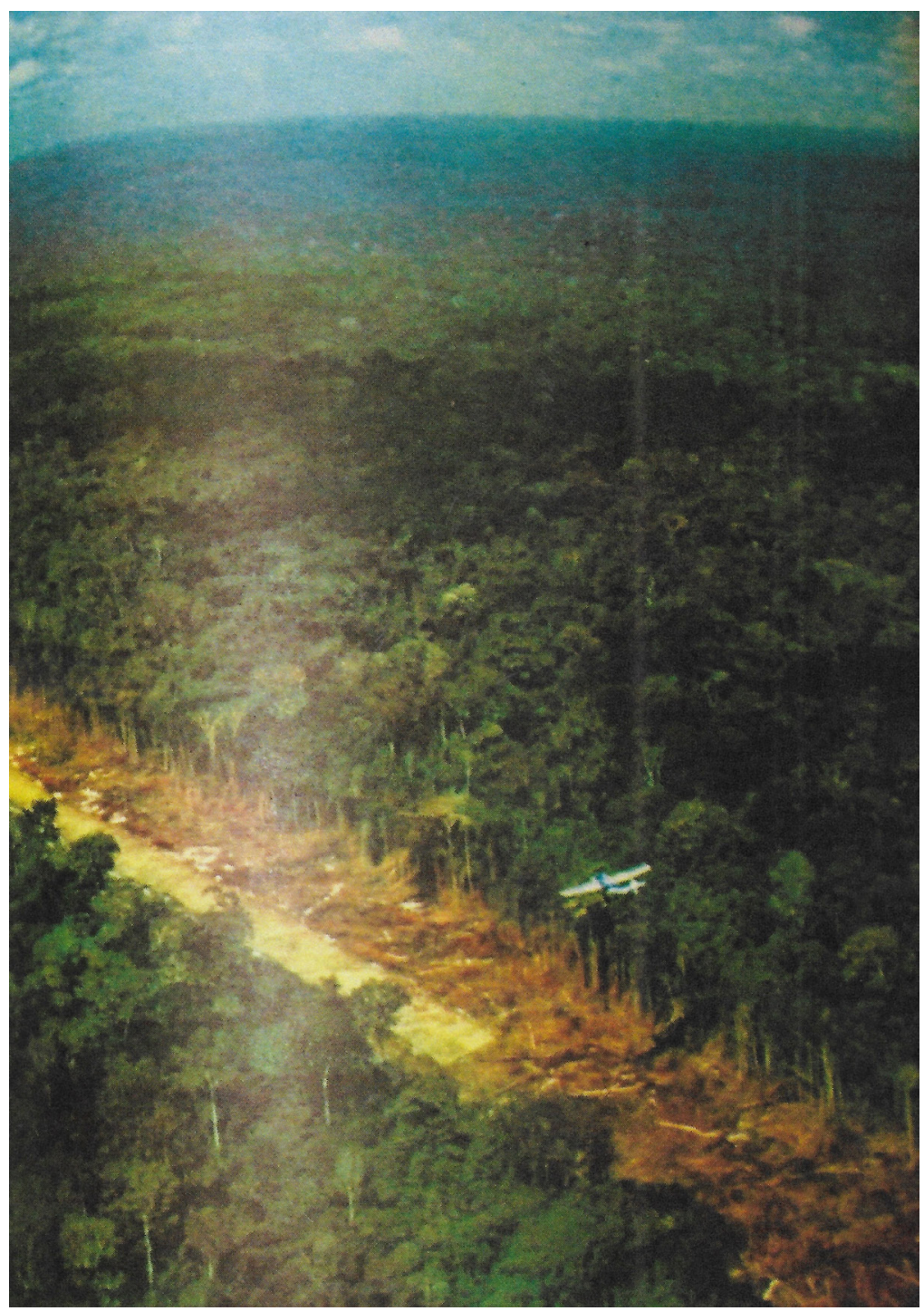

Figura 8 - Campo de pouso improvisado no meio da mata. Fotógrafo não identificado, 1959. Fonte: FLORES, Aluízio. Belém-Brasília: Manchete assiste à conquista da Amazônia. Manchete, Rio de Janeiro, ano 10, n. 7, p. 15-25, 1959. p. 20 
De todas as fontes analisadas, essa foi a única em que encontramos um diálogo, mesmo que distante, com as concepções de proteção e conservação da natureza veiculadas à época. Não obstante silenciadas por uma ampla propaganda, essas ideias existiam e ocuparam um espaço significativo no debate sobre a agenda pública brasileira a partir dos anos 1920. Um grupo de pesquisadores relevantes naquele período, como Alberto Sampaio, Armando Magalhães, Cândido de Mello Leitão e Frederico Hoehne, vinculava preocupações pontuais, como o estabelecimento de reservas naturais, a um projeto mais amplo de nacionalidade. Assim, conseguiram sensibilizar associações cívicas e obter espaço nas instâncias deliberativas do governo Vargas. Esses pesquisadores engajados na proteção da natureza se apropriaram de tradições de pensamento que envolviam um conhecimento científico do mundo natural e a ideia de que esse mundo deveria ser conservado, por motivos econômicos e estéticos. ${ }^{38}$

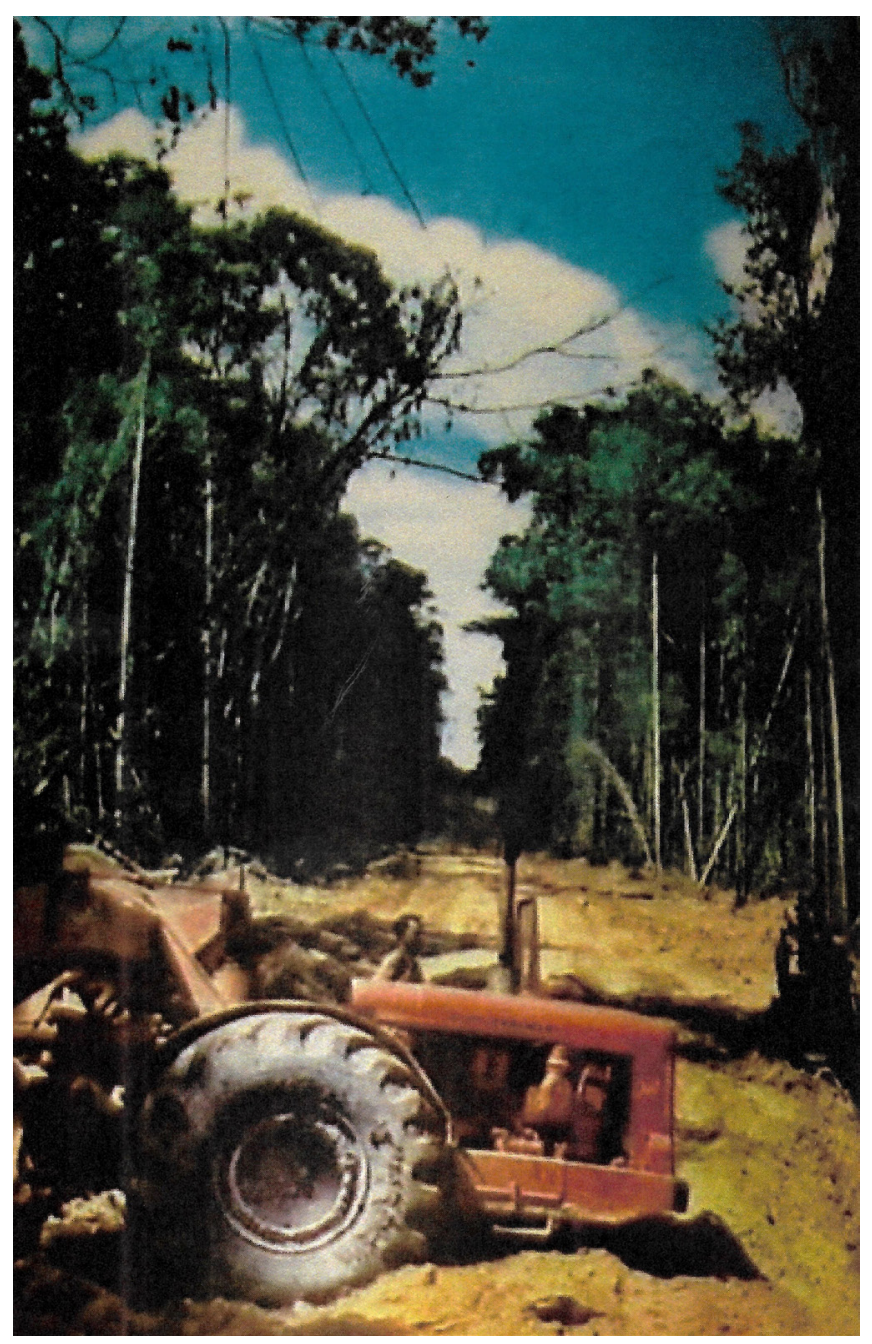

Figura 9 - Abertura de picada na mata. Fotógrafo não identificado, 1959. Fonte: FLORES, Aluízio. Belém-Brasília: Manchete assiste à conquista da Amazônia. Manchete, Rio de Janeiro, ano 10, n. 7, p. 15-25, 1959. p. 20. 
39. Cf. Franco (2009).

40. Cf. Franco (2009).

41. Franco (2009, p. 219).

42. Cf. Dean (2010).
Um exemplo de pensador brasileiro com ideias que podem ser consideradas "conservacionistas" foi Alberto Torres, visto como um crítico da modernidade porque, em seu modo de entender, o progresso do industrialismo vinha acelerando a exaustão dos recursos naturais do planeta. Para Torres, a chave do progresso estaria no uso previdente dos recursos naturais e no investimento em educação e saúde. Entre os anos 1920 e 1940 os conceitos de proteção, conservação e preservação eram intercambiáveis, indicando que a natureza deveria ser protegida tanto como conjunto de recursos produtivos a ser explorado racionalmente conforme interesse das gerações presentes e futuras, quanto como diversidade biológica a ser objeto da ciência e contemplação estética. ${ }^{39}$ Organizações civis, como a Sociedade Geográfica do Rio de Janeiro, o Centro Excursionista Brasileiro e a Sociedade dos Amigos das Árvores, assumiram posturas ativas na preservação da natureza. Criticavam o desmatamento, clamavam por reformas na agricultura, defendiam a promulgação de uma lei florestal, distribuíam sementes e ministravam palestras. O ponto culminante dessa mobilização foi a Primeira Conferência Brasileira de Proteção à Natureza, em 1934. A comissão organizadora, formada por funcionários públicos, cientistas, médicos e professores, buscava concretizar suas propostas por meio de pressão e influência pessoal sobre as autoridades públicas que ocupavam posições de destaque naquela época. $\bigcirc$ entusiasmo presente nas reuniões e deliberações do grupo transformou-se em frustração com a não incorporação das propostas à Constituição brasileira e com a pouca reverberação que essas ideias tiveram na sociedade civil. A razão do fracasso residiria na difusão da ideologia do desenvolvimentismo, que se definia àquela época como corrente hegemônica dentro da articulação política do Estado. ${ }^{40}$ Essa ideia teria galvanizado todos os componentes do espectro político e de todos os grupos sociais. Assim, o desenvolvimentismo presente na sociedade brasileira fez com que muitos recursos naturais fossem intensivamente explorados e consumidos.

No plano mais geral da sociedade e das economias nacionais, prevaleceu o projeto político mais amplo do desenvolvimentismo, que se tornou hegemônico até os dias atuais. Esse projeto prioriza o crescimento econômico, mesmo que às custas da devastação da natureza. Fosse a iniciativa privada ou o Estado a explorar os recursos naturais, a nossa sociedade e os seus governos apoiaram, e continuam a apoiar o crescimento econômico a qualquer custo. ${ }^{41}$

Segundo Warren Dean, o desenvolvimento foi imbuído dos valores positivos de independência e autorrealização; enquanto um sistema de crenças, era milenarista: o atraso se encerraria, o tradicionalismo daria lugar à modernização e o país alcançaria o desenvolvimento, que constituía um patamar edênico de civilização. ${ }^{42}$ Assim, a ideia de desenvolvimento econômico penetraria a 
consciência da cidadania, justificando cada ato de governo e de extinção da 43. Cf. Dean (2010). natureza. ${ }^{43} \bigcirc$ que presenciamos na análise da Belém-Brasília é que tal discurso de progresso, desenvolvimento e demais sinônimos atinge um clímax no governo JK, em especial porque tais concepções estavam entranhadas nos projetos governamentais, como o Plano de Metas. Conforme destacado no artigo, existiram críticas à construção da rodovia baseadas na preservação da natureza, e não meramente em ideias oposicionistas. Porém, o discurso do desenvolvimento aliado ao progresso imbuía-se de valores com forte penetração social e política. Como uma cristalização desse debate, a Figura 10 e sua legenda demonstram o que seria a desejada "integração" do Norte ao restante do Brasil: na prática, uma anexação do "vazio" e da "terra selvagem". Por fim, uma constante nas imagens aqui apresentadas é a antinomia entre humano e natureza, além da associação desta com a ideia de "arcaico", em contraposição ao que seria considerado moderno nos anos JK. A trajetória da Belém-Brasília é uma pequena amostra de um processo extremamente violento de intervenção estatal nos anos 1950, e por mais que vozes dissonantes existissem, elas não tinham reverberação. Posteriormente, nos anos 1970, tal discurso retornaria com contornos igualmente dramáticos, na construção da rodovia Transamazônica. Um objetivo subjacente a este texto foi demonstrar que processos como o aqui descrito lassim como o intenso uso de propaganda políitica) também caracterizaram o período democrático brasileiro.

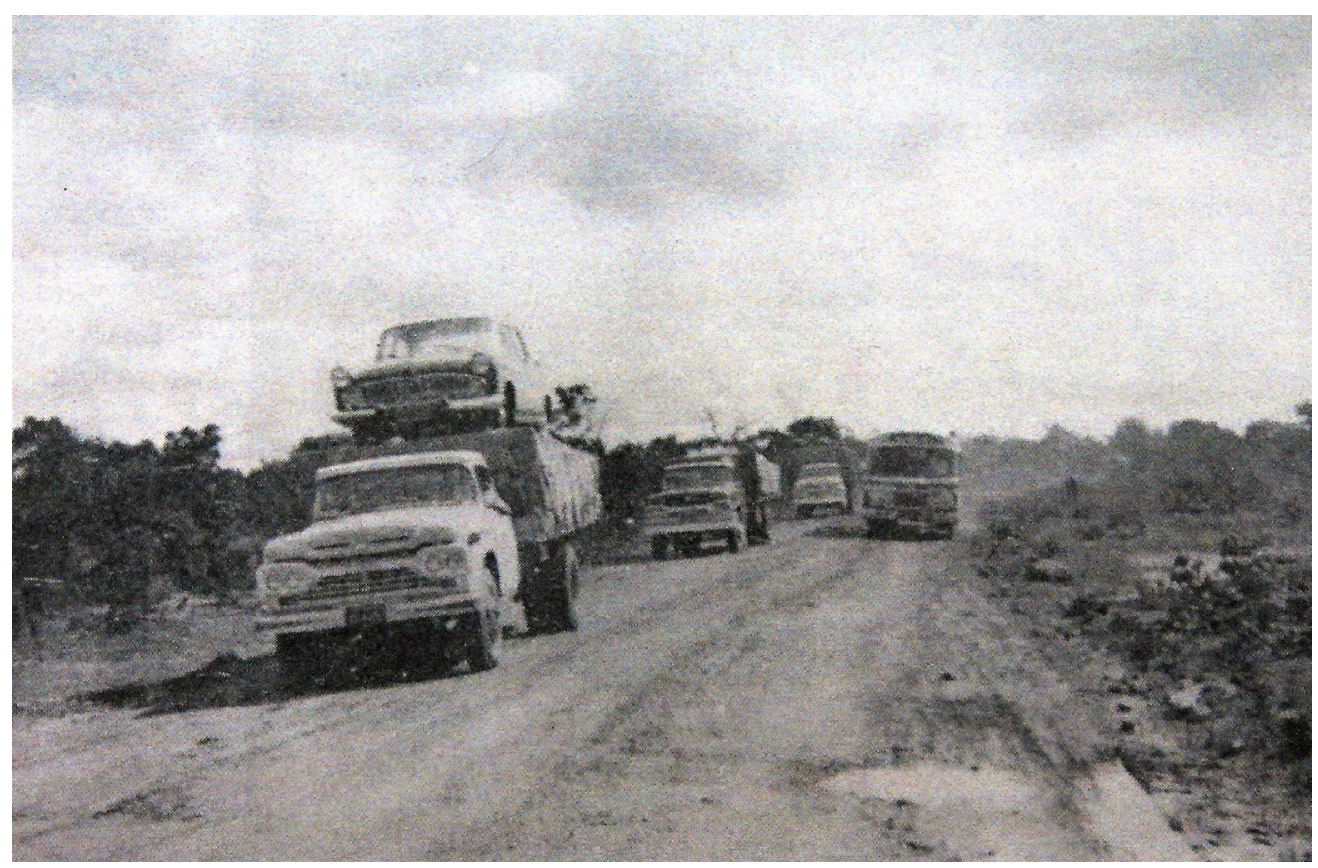

Figura 10 - A indústria do Sul pede passagem para os mercados do Norte. Fotógrafo não identificado, 1960. Fonte: BARRETO, Roberto Menna. Aventura através do progresso. São Paulo: Abril, 1960. p. 10 


\section{REFERÊNCIAS}

FONTES IMPRESSAS

BARRETO, Roberto Menna. Aventura através do progresso. São Paulo: Abril, 1960.

BRASIL. O planejamento transforma a Amazônia. Rio de Janeiro: SPVEA, 1960.

FLORES, Aluízio. Belém-Brasília: Manchete assiste à conquista da Amazônia. Manchete, Rio de Janeiro, ano 10, n. 7, p. 15-25, 1959.

KUBITSCHEK, Juscelino. Por que construí Brasília. Brasília: Senado Federal, 2000. (Brasil 500 Anos).

PIERRE, Arnaud. Primeira viagem na Belém-Brasília. Rio de Janeiro: SPVEA, 1960. (Cadernos Belém-Brasília, v. 4).

LIVROS, ARTIGOS E TESES

BARTHES, Roland. A câmara clara: nota sobre a fotografia. Rio de Janeiro: Nova Fronteira, 2002.

BECKER, Bertha K. Amazônia: geopolítica na virada do III Milênio. Rio de Janeiro, Garamond, 2004.

BIROLI, Flavia. Liberdade de imprensa: margens e definições para a democracia durante o governo Kubitschek (1956-1960). Revista Brasileira de História, São Paulo, v. 24, n. 47 , p. 213-240, 2004.

BIZELLO, Maria Leandra. Imagens otimistas: representações do desenvolvimentismo nos documentários de Jean Manzon. 1995. 250 f. Dissertação (Mestrado em Multimeios) - Universidade Estadual de Campinas, Campinas, 1995.

BORGES, Barsanufo Gomides. Ferrovia e modernidade. Revista UFG, Goiânia, ano 13, n. 11, p. 27-36, dez. 2011.

BORGES, Maria Eliza Linhares. História Efotografia. Belo Horizonte: Autêntica, 2008.

BURKE, Peter. Testemunha ocular: história e imagem. Bauru: Edusc, 2004. 
CORRÊA, Dora Shellard. História ambiental e a paisagem. Halac, Belo Horizonte, v. 2 , n. 1, p. 47-69, set. 2012/fev. 2013.

DEAN, Warren. A ferro e fogo: a história e a devastação da Mata Atlântica brasileira. São Paulo: Companhia das Letras, 2010.

FRANCO, José Luiz de Andrade; DRUMMOND, José Augusto. Proteção à natureza e identidade nacional no Brasil, anos 1920-1940. Rio de Janeiro: Editora Fiocruz, 2009.

HARDMAN, Francisco Foot. Trem-Fantasma: a ferrovia Madeira-Mamoré e a modernidade na selva. São Paulo: Companhia das Letras, 2005.

KOSSOY, Boris. Realidades e ficções na trama fotográfica. São Paulo: Ateliê, 2002.

Fotografia E história. São Paulo: Ateliê, 2001.

LACERDA, Aline Lopes. A fotografia nos arquivos: produção e sentido de documentos visuais. História, Ciências, Saúde-Manguinbos, Rio de Janeiro, v. 19, n. 1, p. 283-302, jan./mar. 2012.

MARTINS, Marcos Lobato. História e meio ambiente. São Paulo: Annablume; Faculdade Pedro Leopoldo, 2007.

MAUAD, Ana Maria. Poses e flagrantes: ensaios sobre história e fotografia. Niterói: Editora da UFF, 2008.

MOREIRA, Vânia Maria Losada. Os anos JK: industrialização e modelo oligárquico de desenvolvimento rural. In: FERREIRA, Jorge; DELGADO, Lucília de Almeida Neves (Orgs.). O Brasil Republicano: o tempo da experiência democrática - da democratização de 1945 ao golpe civil-militar de 1964. Rio de Janeiro: Civilização Brasileira, 2003. p. 357-376.

PÁDUA, José Augusto. As bases teóricas da História Ambiental. In: FRANCO, José Luiz de Andrade et al. História Ambiental: fronteiras, recursos naturais e conservação da natureza. Rio de Janeiro: Garamond, 2012. p.1-11.

Um sopro de destruição: pensamento político e crítica ambiental no Brasil escravista (1786-1888). Rio de Janeiro: Jorge Zahar, 2002.

RICARDO, Cassiano. Marcha para o Oeste: a influência da "bandeira" na formação social e política do Brasil. São Paulo: Edusp; José Olympio, 1970.

ROLIM, Azevedo. Transbrasiliana: poema brasilista. Rio de Janeiro, 1960.

ROSSI, Paolo. Naufrágios sem espectador: a ideia de progresso. São Paulo: Editora Unesp, 2000.

SILVA, Sandro Duarte. A natureza contra o progresso: mitos e narrativas do "destino bandeirante" na expansão desenvolvimentista. Textos de História, Brasília, v. 17, n. 1, p. 85-106, 2009. 
VELHO, Otávio Guilherme. Capitalismo autoritário e campesinato. São Paulo: Difel, 1976.

WORSTER, Donald. Para fazer História Ambiental. Estudos Históricos, Rio de Janeiro, v. 4, n. 8, p. 1-17, 1991 .

Artigo apresentado em 26/06/2017. Aprovado em 05/04/2018.

\section{(c) BY}

All the contents of this journal, except where otherwise noted, is licensed under a Creative Commons Attribution License 